Prepared in cooperation with the City of Lubbock

\title{
Historical Streamflows of Double Mountain Fork Brazos River and Water-Surface Elevations of Lake Alan Henry, Garza County, Texas, Water Years 1962-2010
}

The U.S. Geological Survey (USGS), in cooperation with the City of Lubbock, Texas, operates two surface-water stations in Garza County, Tex.: USGS streamflow-gaging station 08079600 Double Mountain Fork Brazos River at Justiceburg, Tex. (hereinafter, Double Mountain Fork Brazos station), and 08079700 Lake Alan Henry Reservoir near Justiceburg, Tex. (hereinafter, Lake Alan Henry station), a water-supply reservoir about 60 miles southeast of Lubbock, Tex., and about 10 miles east of Justiceburg, Tex. The Double Mountain Fork Brazos River locally is also known as the "South Fork Double Mountain Fork Brazos River" and is often referred to as the "South Fork." The streamflow and water-surface elevation data from the two stations are useful to water-resource managers and planners in support of forecasting and water-resource infrastructure operations and are used in regional hydrologic studies.

The Double Mountain Fork Brazos station has a 1,466 square mile watershed but a contributing drainage area of only 244 square miles. This station is currently (2012) the most upstream continuous record streamflow station in the greater Brazos River basin of Texas. The station is upstream from Lake Alan Henry, and as a result, the Double Mountain Fork Brazos station also provides reservoir inflow data (streamflow, in cubic feet per second). The Lake Alan Henry station provides water-surface elevation of the reservoir, which has a 1,617 square mile watershed but a contributing drainage area of only 395 square miles. Figure 1 shows the locations of Lake Alan Henry, the Lake Alan Henry station, and the Double Mountain Fork Brazos station. The Double Mountain Fork Brazos River and Sand Creek are principal tributaries for the lake. This fact sheet highlights some of the data and ancillary information collected by the two stations. The data for these two stations are available through the USGS National Water Information System (U.S. Geological Survey, 2011).

\section{Lake Alan Henry}

The completion of the Lake Alan Henry water-supply infrastructure has taken on particular importance because of diminished water availability from Lake Meredith near Amarillo, Tex. (Blackburn, 2009). Lake Meredith historically

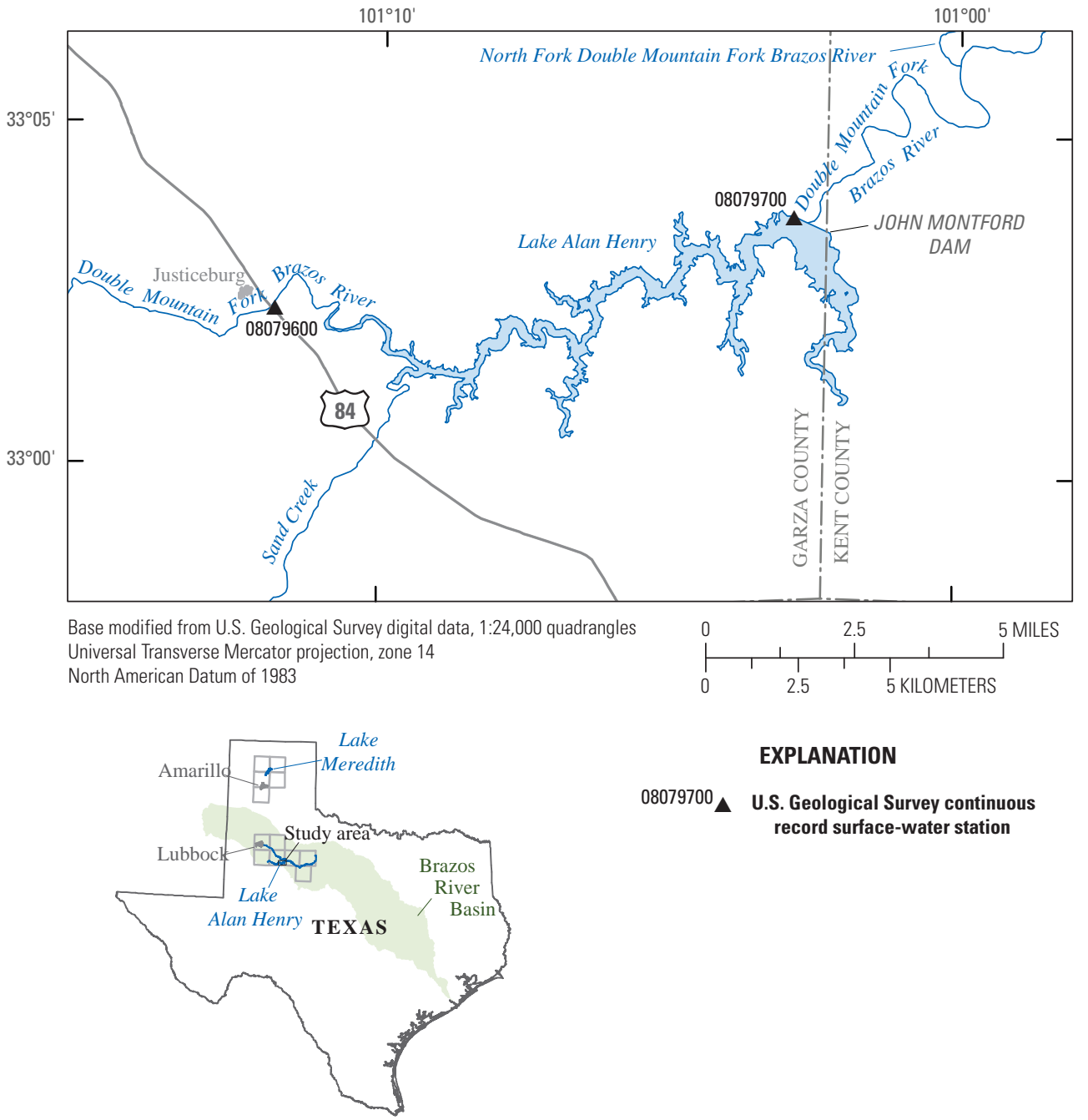

Figure 1. Location of U.S. Geological Survey surface-water stations in Garza County, Texas. 
has been the primary surface-water supply for Lubbock and other communities in the region. Construction of the John Montford Dam, which impounds Lake Alan Henry, began in 1991 and was completed in October 1993. The conservation pool elevation of the reservoir is 2,220 feet National Geodetic Vertical Datum of 1929. The USGS has collected hydrologic data at the Lake Alan Henry station since October 1, 1997. The first substantial inflows to the reservoir occurred in the first half of 1999 and began a period of increasing water-surface elevations in the reservoir that lasted about 5 years (resulting in a net increase in water-surface elevation of almost 40 feet). The reservoir attained conservation-pool elevation (2,220 feet) for the first time around October 3, 2004. The original and primary purpose of the Double Mountain Fork Brazos station was to assess water availability as part of the planning process for Lake Alan Henry. After the completion of the reservoir and from the mid 1990s onward, the Double Mountain Fork Brazos station has provided long-term monitoring of inflows to Lake Alan Henry.

The City of Lubbock (2011) reported that the firm yield of Lake Alan Henry is 19,000 acre-feet of water and that the reservoir can supply more than 40 percent of the current (2011) water-supply needs of Lubbock. The City of Lubbock (2011) also reported that some time in 2012 a raw-water pipeline from the reservoir to a new water-treatment plant in southeast Lubbock is expected to be completed. The new plant will contribute drinking water to the municipal distribution system in Lubbock.

\section{Streamflow Data for Double Mountain Fork Brazos River}

Two primary data products for the Double Mountain Fork Brazos station are daily mean values (DVs) and instantaneous values, also called unit values (UVs), of river stage (height referenced to a measurement datum) and more importantly streamflow. The daily value data for the station can be accessed at http://waterdata.usgs.gov/tx/nwis/dv/? site_no $=08079600$, and the unit-value data can be accessed at http://waterdata.usgs. gov/tx/nwis/uv/? site_no $=08079600$. Other data types and time periods also can be acquired by using these two Web sites. An example figure of DVs for the period of December 1, 1961 through September 30, 2010 is shown in figure 2, which was retrieved through the first Web site shown in this paragraph.

The USGS has previously published several data reports (Asquith and others, 2007a, b; Asquith and Heitmuller, 2008) that provide summaries of streamflow history throughout Texas. The Double Mountain Fork Brazos station is included within each of these reports. The top graph in the figure shows that the number of days with zero flow represents about 46 percent of the water year; streamflows at this station are ephemeral, and substantial inflows to Lake Alan Henry occur as storm runoff during periods of abundant rainfall. Distinctive patterns in number of zero-flow days in water years is evident with some water years, particularly before the early 1990s, having fewer zero-flow days compared to other water years. Relatively more zero-flow days occurred since the early 1990s. The bottom graph in figure 3 represents the zero-flow potential by month across years. Two peaks representing highest potential for zero flow occur around April and July. The months of January and December are least likely to have zero-flow conditions.
USGS 08079600 DMF Brazos Rv at Justiceburg, TX

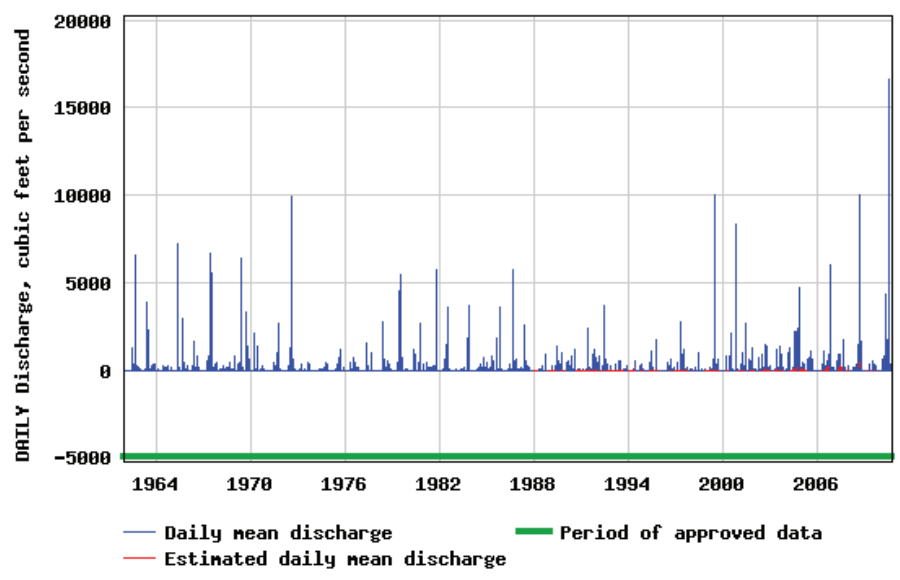

Figure 2. Period of record retrieval of daily mean streamflow for U.S. Geological Survey streamflow-gaging station 08079600 Double Mountain Fork Brazos River at Justiceburg, Texas, for the period December 1, 1961 through September 30, 2010.

A summary of annual mean, maximum, minimum, and L-scale (a linear measure of variability) statistics of the daily mean streamflow for each water year (1963-2010) at the Double Mountain Fork Brazos station is shown in figure 4. The mean streamflow (top) graph in the figure is perhaps the most important from the perspective of water supply. The mean annual streamflow is computed as 30.3 cubic feet per second (approximately 21,900 acre-feet per year, which compares favorably with the City of Lubbock's [2011] yield for planning of 19,000 acre-feet). The flood event after Hurricane Alex (fig. 5), occurring during water year 2010, contributed substantially to the largest annual volume since at least 1963. The maximum daily streamflow (top middle) graph demonstrates considerable interannual variation in the annual maximum daily mean flow, which is typical of many river systems in Texas. The minimum daily streamflow (lower middle) graph complements figure 3 and shows that zero-flow conditions occur every year. Lastly, the L-scale streamflow (bottom) graph shows an apparent consistency in the intraannual variation in streamflow shown in the top graph.

Asquith and Heitmuller (2008, p. 556) provided period of record and last decade (1997-2007) flow-duration curves for the Double Mountain Fork Brazos station. These curves indicate (along with a plot of the period of record of DVs from the same report) that the streamflow characteristics (statistical properties) of the Double Mountain Fork Brazos station above Lake Alan Henry during 1997-2007 visually appear similar to those for the period of record analyzed (1962-2007). The mean streamflow (1962-2007) for the Double Mountain Fork Brazos station is reported by Asquith and Heitmuller (2008 p. 557) as about 28 cubic feet per second. This streamflow value is about the 90th percentile of daily flows, which is indicative of a river basin for which the storm flow or flood volume represents a critical contribution to overall volume (yield) of the Double Mountain Fork Brazos River above Lake Alan Henry. 


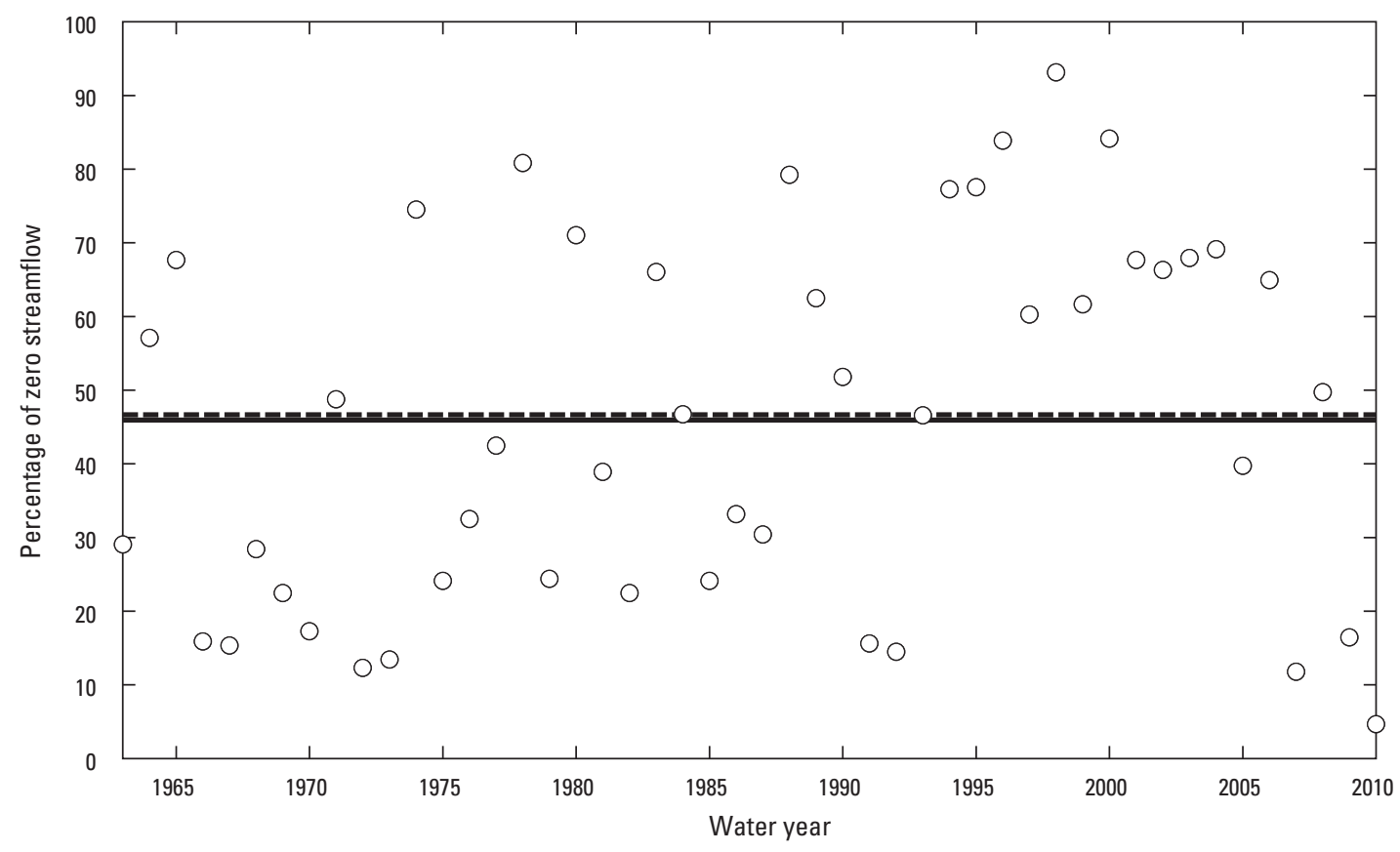

EXPLANATION
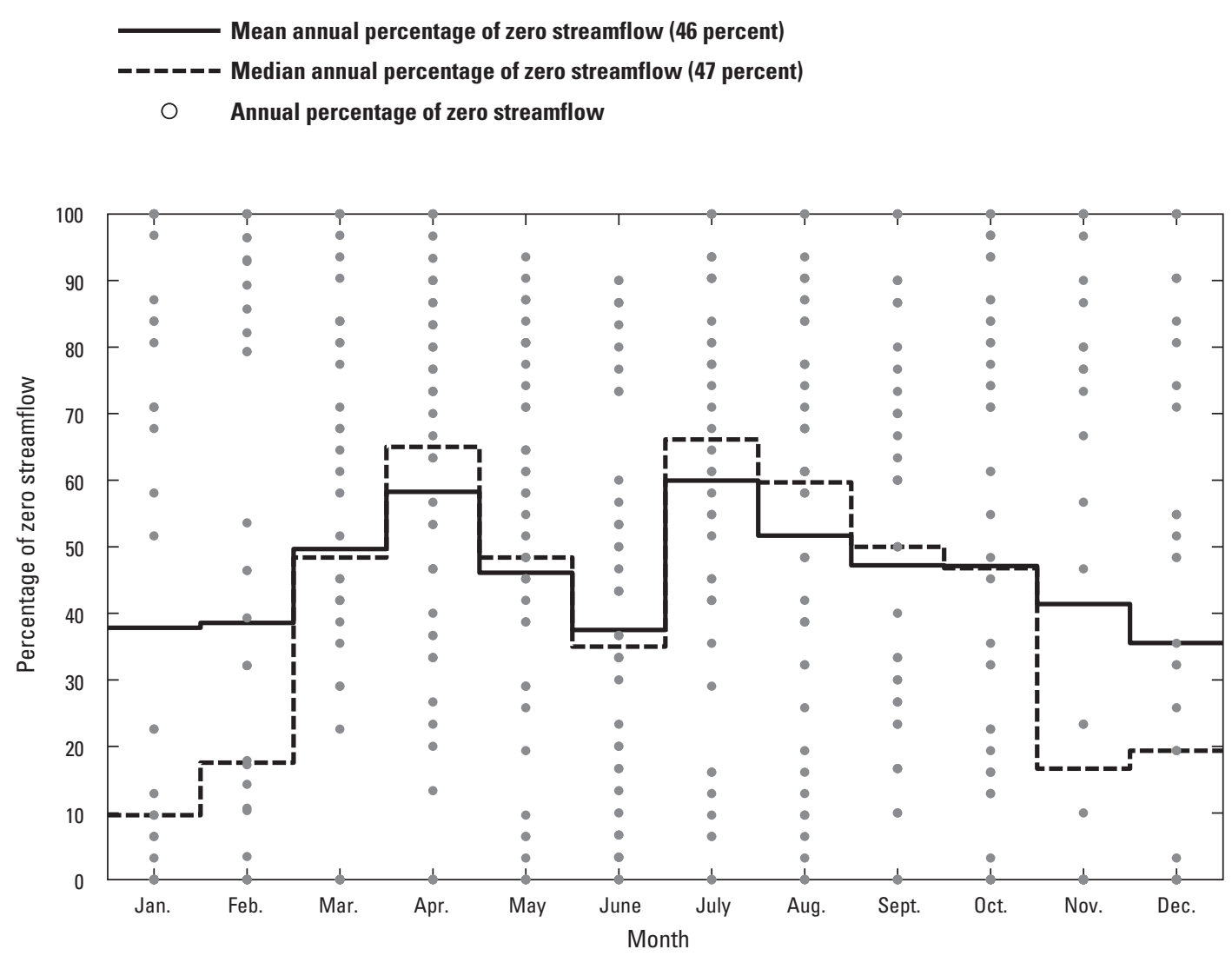

EXPLANATION

Mean monthly percentage of zero streamflow

----ー- Median monthly percentage of zero streamflow

- Percentage of zero streamflow for indicated month for a given calendar year

Figure 3. Summary of percentage of zero daily mean streamflow for U.S. Geological Survey streamflow-gaging station 08079600 Double Mountain Fork Brazos River at Justiceburg, Texas (modified from Asquith and others, 2007a). 


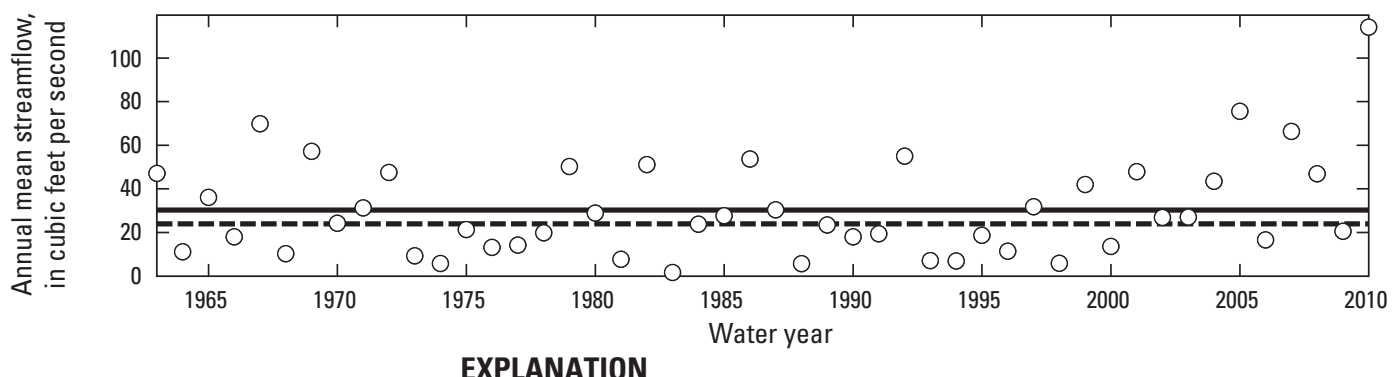

\section{EXPLANATION} \begin{tabular}{ll} 
& Mean annual mean streamflow (30.3 cubic feet per second) \\
\hline 0 & Annual mean streamflow
\end{tabular}

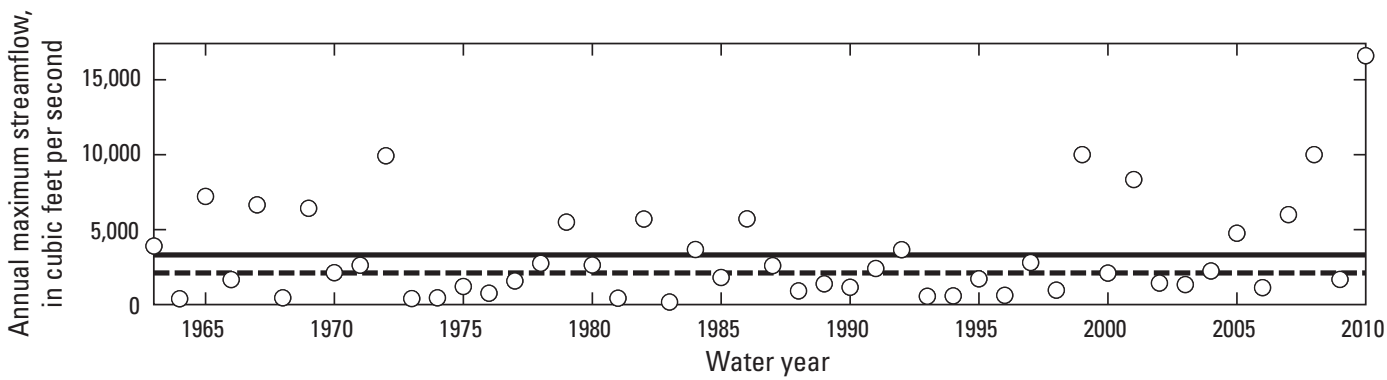

EXPLANATION

Mean annual maximum streamflow (3,310 cubic feet per second)

- - - - Median annual maximum streamflow (2,110 cubic feet per second)

$\bigcirc$ Annual maximum streamflow

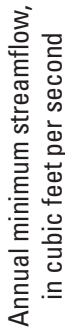

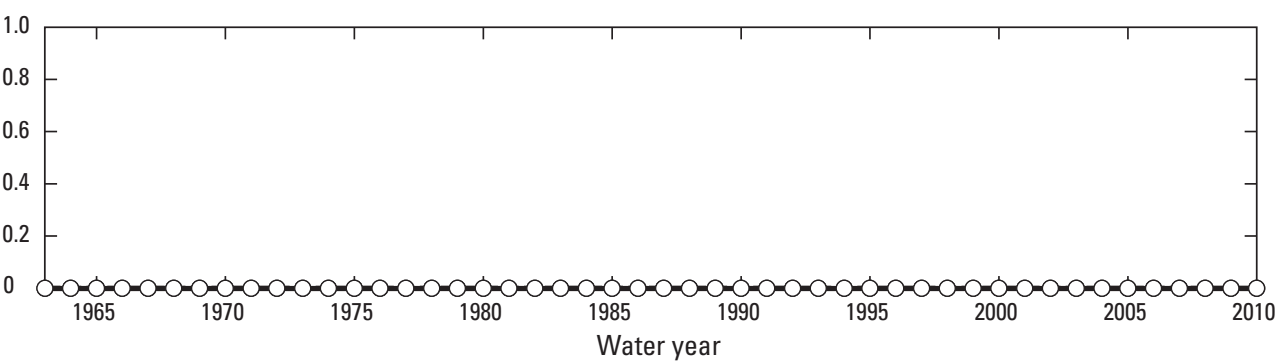

EXPLANATION

Mean annual minimum streamflow (0 cubic feet per second)

- -n-.. Median annual minimum streamflow (0 cubic feet per second)

○ Annual minimum streamflow

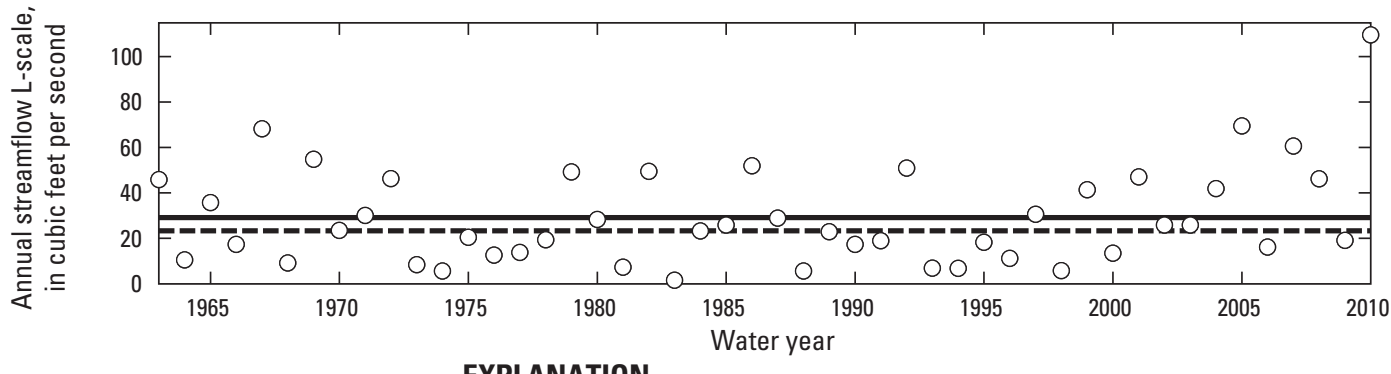

EXPLANATION

Mean L-scale of annual streamflow (29.1 cubic feet per second)

-----. Median L-scale of annual streamflow (23.3 cubic feet per second)

O Annual L-scale of streamflow

Figure 4. Summary of annual mean, maximum, minimum, and L-scale statistics of daily mean streamflow for U.S. Geological Survey streamflow-gaging station 08079600 Double Mountain Fork Brazos River at Justiceburg, Texas (modified from Asquith and others, 2007b). 


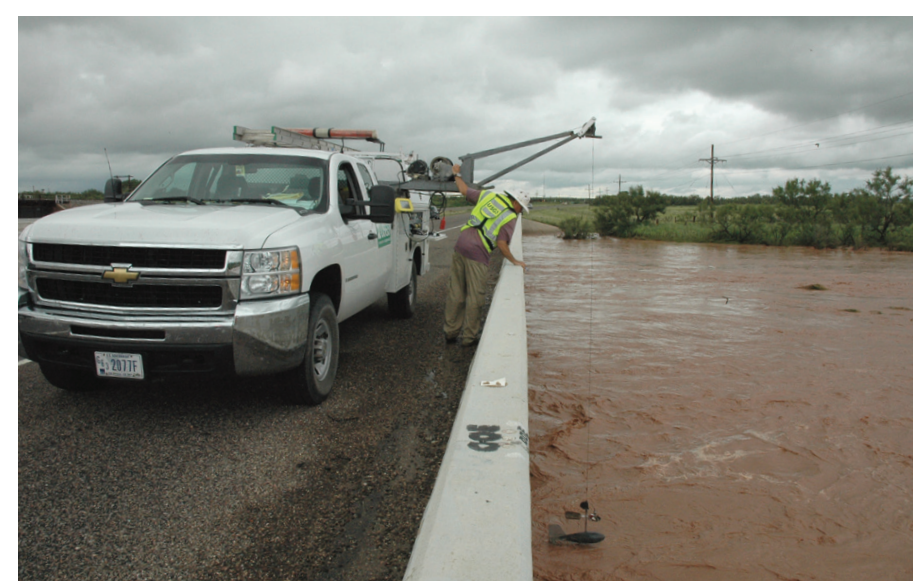

\section{Water-Surface Elevation Data for Lake Alan Henry Reservoir}

Two primary data products for the Lake Alan Henry station are DVs and UVs of water-surface elevations (http://waterdata. usgs.gov/tx/nwis/dv/? site_no $=08079700$ and http://waterdata. usgs.gov/tx/nwis/uv/? site_no $=08079700$, respectively). A more elaborate summary of the water-surface elevation data than available in those data products is shown in figure 6 . The figure shows that water-surface elevations have met or exceeded the
Figure 5. Hydrographer performing a measurement of streamflow at U.S. Geological Survey streamflow-gaging station 08079600 Double Mountain Fork Brazos River at Justiceburg, Texas, during a large flood event on July 4, 2010, that resulted from the remnants of Hurricane Alex (Hydrometeorological Prediction Center, 2010, photograph by William H. Asquith).

conservation pool elevation of 2,220 feet since about 2005 through the present with substantial inflow events occurring about every 2 years. These events are seen as the "spikes" in the time series (top graph) exceeding about 2,220 feet. The bottom graph of the figure also shows that the 2010 water year had several elevations higher than the mean daily mean and that the modest inflow event in late April 2010 and a larger event around July 4 set numerous daily maximum elevation values for the period of record.

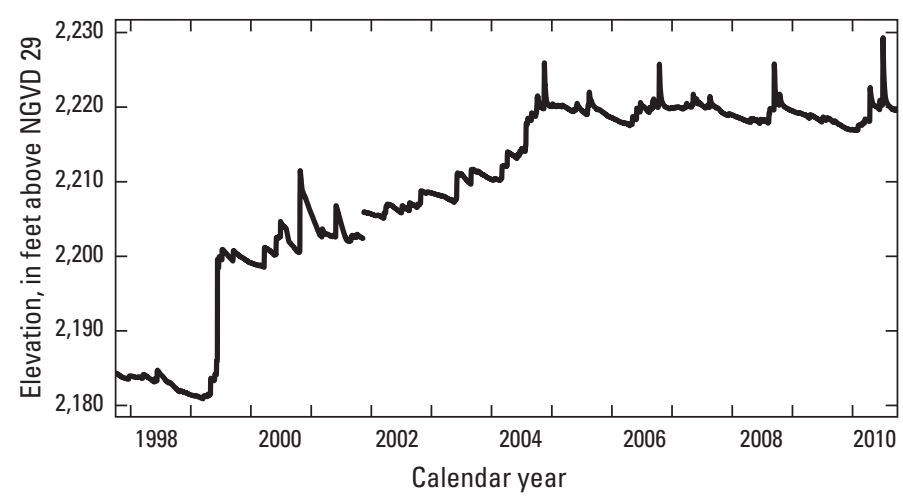

\section{EXPLANATION}

Daily mean elevation above NGVD 29

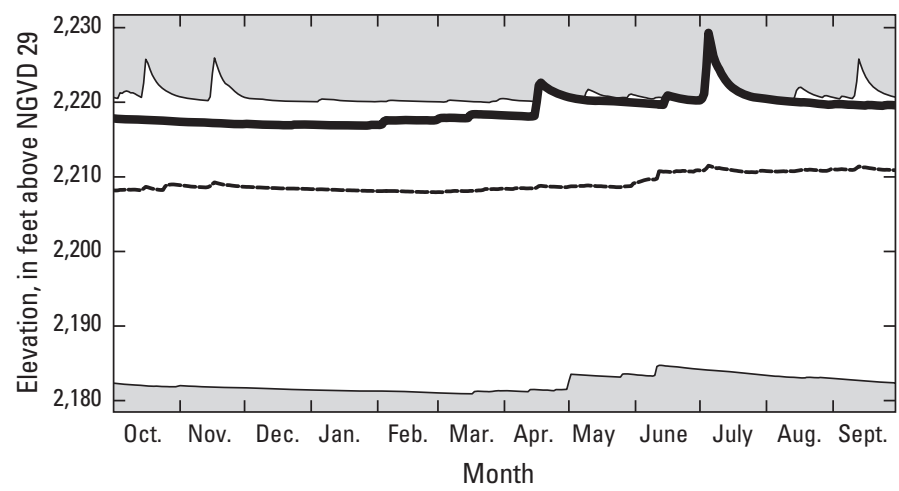

Figure 6. Water-surface elevation National Geodetic Vertical Datum of 1929 (NGVD 29) for U.S. Geological Survey station 08079700 Lake Alan Henry Reservoir near Justiceburg, Texas (modified from Asquith and others, 2007c).

\section{EXPLANATION}

Daily mean elevation above NGVD 29 for water year 2010

Mean daily mean elevation above NGVD 29 for period of record

Maximum or minimum daily mean elevation above NGVD 29 for period of record 


\section{Cited References}

Asquith, W.H., and Heitmuller, F.T., 2008, Summary of annual mean and annual harmonic mean statistics of daily mean streamflow for 620 U.S. Geological Survey streamflowgaging stations in Texas through water year 2007: U.S. Geological Survey Data Series 372, 1,259 p. (Also available at http://pubs.usgs.gov/ds/372/.)

Asquith, W.H., Vrabel, Joseph, and Roussel, M.C., 2007a, Summary of percentages of zero daily mean streamflow for 712 U.S. Geological Survey streamflow-gaging stations in Texas through 2003: U.S. Geological Survey Data Series 247, 721 p. (Also available at $h$ ttp://pubs.usgs.gov/ds/2007/247/.)

Asquith, W.H., Vrabel, Joseph, and Roussel, M.C., 2007b, Summary of annual mean, maximum, minimum, and L-scale statistics of daily mean streamflow for 712 U.S. Geological Survey streamflow-gaging stations in Texas through 2003: U.S. Geological Survey Data Series 248, 721 p. (Also available at http://pubs.usgs.gov/ds/2007/248/.)

Asquith, W.H., Vrabel, Joseph, and Roussel, M.C., 2007c, Summary of water-surface-elevation data for 116 U.S. Geological
Survey lake and reservoir stations in Texas and comparison to data for water year 2006: U.S. Geological Survey Data Series 287, 42 p. (Also available at http://pubs.usgs.gov/ds/287/.)

Blackburn, Elliott, 2009, Water Woes-Officials study possible action as Lake Meredith's water level recedes to 50 feet: Lubbock Avalanche-Journal, accessed May 9, 2011, at http://lubbockonline.com/stories/061809/loc_452080824. shtml.

City of Lubbock, 2011, Lake Alan Henry Pipeline UpdateLubbock's Water Project Moves Forward: Water Conservation and Education Department, accessed May 5, 2011, at http://water.ci.lubbock.tx.us/pdf/news/Advertorial02.pdf.

Hydrometeorological Prediction Center, 2010, Hurricane Alex-June 29-July 6, 2010: National Weather Service Hydrometeorological Prediction Center, accessed May 10, 2011, at http://www.hpc.ncep.noaa.gov/tropical/rain/ alex2010.html.

U.S. Geological Survey, 2011, National Water Information System, accessed May 2011, at http://waterdata.usgs.gov/tx/ nwis/.

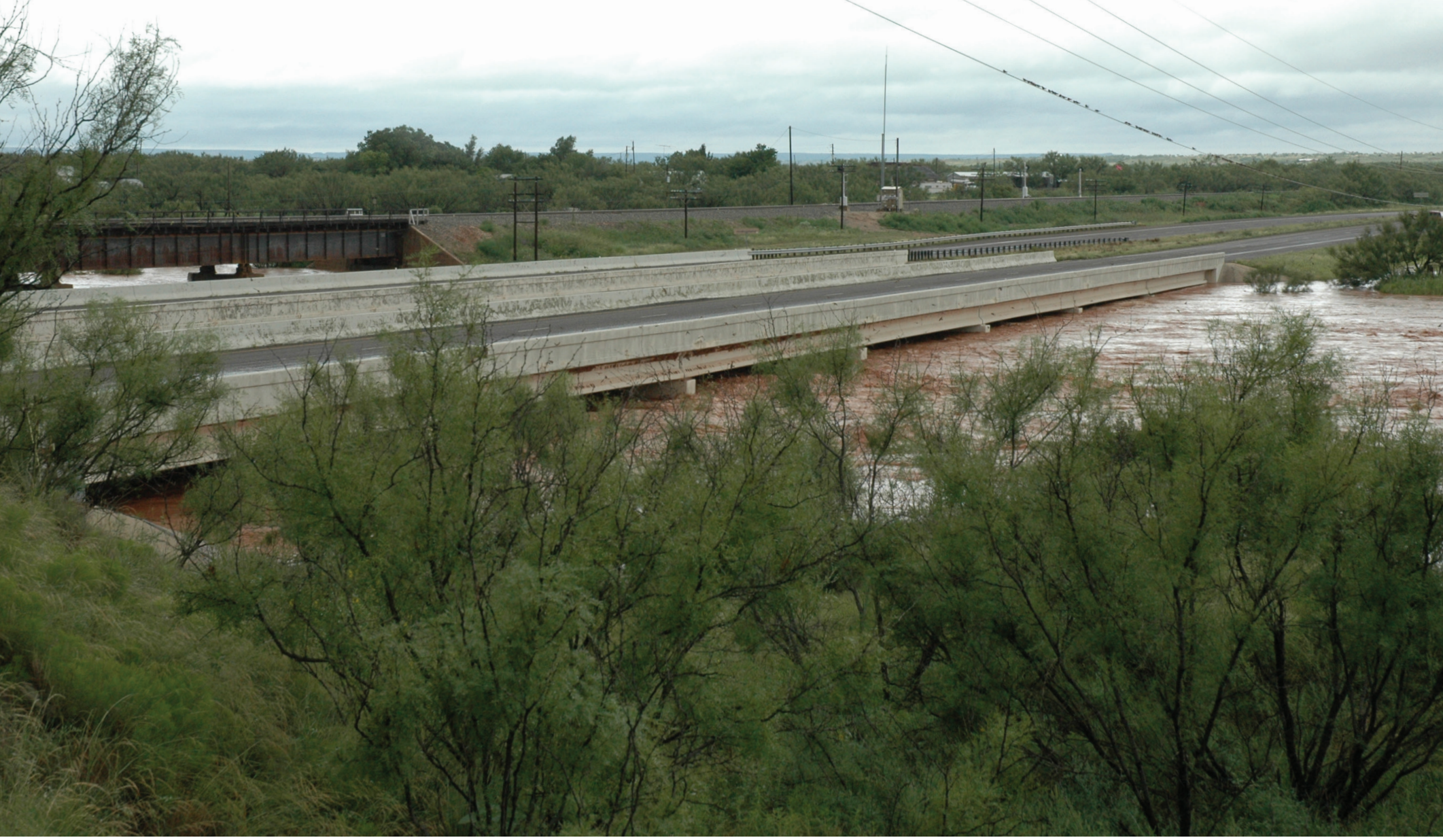

-William H. Asquith and J oseph Vrabel

Publishing support provided by

Lafayette Publishing Service Center

\section{For additional information, contact}

Director, USGS Texas Water Science Center

http://tx.usgs.gov/

gs-w-txpublic-info@usgs.gov 